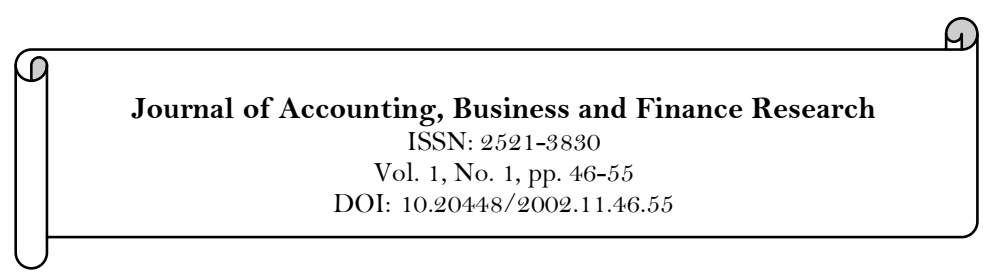

\title{
Working Capital Management and Managerial Performance in some Selected Manufacturing Firms in Edo State Nigeria
}

\author{
Jones Osasuyi, Orumwense ${ }^{1}$ \\ Greenfield Mwakipsile ${ }^{2}$ \\ 1,2Namibia Business School, University of Namibia.
}

\begin{tabular}{l|l}
\multicolumn{4}{c}{ Abstract } & \\
$\begin{array}{l}\text { This study was conducted to correlate working capital } \\
\text { Management's impact to Managerial Performance in Some selected }\end{array}$ & $\begin{array}{l}\text { Keywords: } \\
\text { Working capital management } \\
\text { managerial performance and }\end{array}$ \\
Manufacturing Firms in Edo State Nigeria. The study was \\
conducted through descriptive survey and correlation research \\
Organisations.
\end{tabular}

\section{Introduction}

The efficient management of working capital is very vital for every business survival. This is premised on the fact that having too much working capital signifies efficiency, whereas too little cash at hand signifies that the survival of business is shaky (Padachi, 2006).

Over the years there has been a big debate on the effect of working capital policy on the profitability. Other researchers support companies to have a working capital policy because they believe that proper management of components of working capital can balance cost and benefit of the company and it will reduce the risk of default by raising the level of liquidity.

Some research studies have been undertaken on the working capital management practices of large companies, small firms, manufacturing companies, telecommunication companies, and so forth in UK, USA, and Belgium using either a survey based approach (to identify the push factors for firms to adopt good working capital management policies or econometric analysis to investigate the association between WCM and profitability (Deloof, 2003). In Sweden research was carried out with the purpose to explore relationship between working capital policy and profitability of firms.

Some other researchers were conducted especially in developing countries like Pakistan, India, Taiwan etc. (Ghosh \& Maji, 2003) made an attempt to examine the efficiency of WCM of the Indian cement companies during 1992-1993 to 2001 - 2002. For measuring the efficiency of WCM, performance, utilization, and overall efficiency indices were calculated instead of using some common working capital management ratios. Setting Industry norms as target efficiency levels of efficiency by an individual firm during the period of study Findings of the study indicated that the Indian Cement Industry as a whole did not perform remarkably well during this period.

Published article on WCM in Africa, specifically in South Africa where they emphasized that those who promoted working capital theory shared that profitability and liquidity comprised the salient goals of working capital management. The problem arose because the maximization of the firm's returns could seriously threaten its liquidity, and the pursuit of liquidity had a tendency to dilute returns. This article evaluated the association between traditional and alternative working capital measures and return on investment (ROI), specifically in industrial firms listed on the Johannesburg Stock Exchange (JSE). Also, research study was conducted exclusive on the impact of working capital management on corporate profitability of small manufacturing companies in Mauritius (Padachi, 2006). 
In Nigeria there are no such studies relation to working capital management, and every business entity, regardless of its business types, needs working capital management.

\subsection{Problems Statement}

Efficient management of working capital, maximization of returns which seriously threatens liquidity, and pursuit of liquidity had a tendency to dilute returns are the challenges of working capital management for the manufacturing firm in Edo State Nigeria.

Managing working capital in perspective i.e. aggregative approach will lead to full, utilization of short and long-term assets and henceforth contribute to good managerial performance.

The observation of this fact motivated the researcher to carry out the research on the working capital management and managerial performance of the selected manufacturing firms in Edo State Nigeria.

\section{Purpose of Study}

The purpose of the study is to:

1. To test the hypothesis of no significant relationship between levels of working capital management and managerial performance

2. To bridge the gaps identified in the related studies.

3. This validates existing information about working capital management and managerial performance based on the theory to which this study is based.

\subsection{Research Objective}

General: This study will correlate working capital management and organizational performance in selected manufacturing firm in Edo State, Nigeria.

Specific Objective

1. To determine the demographic characteristics of the respondents in terms of age, gender, education qualifications, and years in the present position.

2. These determine the current level of working capital management of the firms selected.

3. The determine the current level of staff performance of the firms selection.

4. To establish if there is a significant relationship between the levels of working capital management and managerial performance of selected manufacturing firms.

\subsection{Research Questions}

1. What are the demographic characteristics of the respondents in terms of age, gender, education qualifications, and year in the present poison?

2. What is the current level working capital management of the firms selected?

3. What is the current level of staff performance of the first selected?

4. It there any significant relationship between the levels of working capital management and staff performance of the selected manufacturing firms?

\subsection{Null Hypothesis}

There is no significant relationship between the levels of working capital management and managerial performance.

Scope

\subsection{Geographical Scope}

The study will be inducted in selected manufacturing firms in Edo State, Nigeria.

\subsection{Content Scope}

The study intends to examine the levels of working capital management and managerial performance, and to correlate if there is a significant relationship. It will be conducted on officials in some selected manufacturing firms in Edo State Nigeria from $2015-2017$.

\subsection{Time Scope}

The study was conducted from January 2015 to December 2017.

\subsection{Theoretical Scope}

A theory by the name of Perspective Theory developed by McInnes, Angelique Nadia Sweetman (2000) was proven.

Significance of the Study

The following disciplines will benefit from the findings of the study 
The employees of the selected firms will recognize the roles they have to play in fulfilling good working capital management practices in order to maximize the wealth of the firm.

The managers of the concerned firms will achieving the goal of adopting good working capital management policies, realized a satisfying level of performance and appreciate the contribution of the staff and resources available towards a better standard of working capital level for their respective firms. The future researchers in this area will utilize the findings of the study to embark on a relating study.

\section{Review of Related Literature}

\subsection{Working Capital Management}

Working capital is that part of a film's capital which is required to hold current assets of the firm. Examples of current assets are raw material, semi- finished goods, finished goods, debtors, bills receivable, prepaid expenses, cash at bank and cash in hand. The firm required cash to pay various expenses like wages, salaries, rent; advertising etc. Current assets have a short life span. They are swiftly transformed into other current asset forms and ultimately in cash. In other words, funds invested in current assets are constantly converted into cash. This cash again flows out in exchange for other current assets. There is an operating cycle. Cash is used to buy raw material. Various manufacturing expenses are incurred to convert raw material into semi - finished goods and then into finished goods. On sale of finished goods on credit, trade debtors or bills receivable result. On receipt of payment, trade debtors and bills receivable are converted into cash and a cycle of working capital is completed. In case of cash sales, finished goods will directly be converted into cash. The cash is once again used to buy raw material to start another cycle.

As current assets keep circulating or revolving fast, working capital is also called circulating capital, revolving capital or short-term capital.

There are two concepts of working capital namely, gross working capital and net working capital management. Gross working capital is referred to total of all the current assets of the firm. Current assets are the assets which are meant to be converted into cash within a year or an operating cycle. Stock of raw materials, stock of semi- finished goods, stock of finished goods, trade debtors, bills receivable, prepaid expenses, cash at bank and cash in hand are examples of current assets. Networking capital arises when to finance current assets, in which long - term funds as well as short term funds are used. Short - term funds are provided by current liabilities i.e. claims of outsiders which are expected to mature for payment within a year. Tread creditors, bills payable and outstanding expenses are examples of current liabilities. Net working capital refers to the excess of current assets over current liabilities.

Another aspect of the gross working capital points to the need of arranging funds to finance current assets. Whenever a need for working capital funds arises due to the increasing level of business activity or for any other reason, financing arrangement should be made quickly. Similarly, if suddenly, some surplus funds arise they should not be allowed to remain idle, but should be invested in short-term securities (Karthikeyan, 2011).

Working capital management consists of three major components namely: cash management, receivables management, and inventory management.

\subsection{Cash Management}

Cash is the most important current asset for the operations of the business. Cash is the basic input needed to keep the business running on a continuous basis; it is also the ultimate output expected to be realized by selling the service or product manufactured by the firm. The firm should keep sufficient cash, neither more nor less. Cash shortage will disrupt the firm's manufacturing operations, while excessive cash will simply remain idle without contributing anything towards the firm's profitability. Thus, a major function of the financial manager is to maintain a sound cash position.

Cash is the money which a firm can disburse immediately without any restriction. The term cash include coins, currency and cheques held by the firm, and balanced in its bank account. Sometimes near - cash items, such as marketable securities or Bank time deposit, are also included in cash. The basic characteristic or near cash assets is that they can readily be converted into cash. Generally, when a firm has excess cash, it invests it in marketable securities. This kind of investment contributes some profit to the firm (Mathur, 2010). 'One of the first things that successful businesses did during the recession was to look at their borrowing and renegotiate the terms to something that, while it may be over more years and ultimately more expensive, has lower payments now. Yes, adding more debt is probably a bad idea for most business, but if refinancing existing debt allows you to stay in business, there's a definite upside to doing it.

Other businesses negotiated longer periods for making payments to suppliers, while at the same time requiring faster payments from customers.

Another way the recession - surviving businesses management cash flow was to manage how much inventory was being carried at any given time - inventory cost money, and inventory which sits on your stock - room floor for weeks has an opportunity cost which can bankrupt your business (Connor, 2011). The least desirable expense control is always in human resources, but as orders reduced, many manufacturing business laid of staff, instituted freezes or cuts to pay and benefits, reduced investment in hiring and training. 
Connor concludes, 'On the other side of things, the making money flow inside, there were a few tricks, too.

Folks often receive misguided advice concerning cash flow management. Sales volume is important to a successful business, as is the timing of sales and payments. Cash flow is primarily the difference between cash coming into the business and cash going out of the business during a given time period. But every business has a cash cycle. The cash that comes into the business does not always correspond to the same time or same rate as the cash that goes out. It is practically impossible to iron out all the discrepancies in cash inflows and outflow and do a perfect job of controlling and coordinating the movement of cash in a business. But it is possible to develop an understanding the movement of cash in a business. But it is possible to develop an understanding, appreciation and consciousness of cash flow. This is often the first critical step in managing the cash flow of a business.

Financial management educators often compare cash in a simple business with blood in the human body. Cash is often described as the life-giving fluid that keeps a business going. So, if cash is the blood of a business, cash flow is the circulation of the blood throughout the system. Circulation involves both cash flowing in and out of the business.

However, just because blood circulates through the body does not ensure a good blood pressure. The same is true for cash and a business. Simply generating sales revenue does not ensure that a business must be monitored through proper cash flow management. Many same businesses not that cash flow is a big problem/obstacle to their business success. Lack of available cash can weaken a business and even lead to business failure.

Cash that flow irregularity and unpredictability can be as desirous as no cash at all. Effective cash flow management addressed both short - term and long term planning.

Managing cash flow is really nothing more than managing information. Cash flow management is critical to all businesses, but is probably most critical for business whose trading can seasonal and unpredictable. Short - term cash flow management strategies rely on record - keeping systems that provide quick and accurate access to revenue and expenditure transactions. Important information from cash flow management can be obtained from a variety of sources including procedure manuals, bank statement, cash flow forecasts, reports on debt collection and accounts payable. Routine cash management reviews must keep a close eye on debts collection, sales and deliveries, status of invoices, receipt of payments and depositing of payments.

The best cash flow management strategies usually result form system that are fully understood by the cash flow manager. Sometimes such systems are computerized, while others are manual. Cash flow management does not need to be complex to be effective. It does, however, have to be performed. There is no magical solution to managing cash flow. Like the commercial.... 'Just do it." While a computer and proper software program may expedite, simplify and standardize financial information, the information must be studied and monitored in a way that allows for adjustments to be made in the business' activities.

\subsubsection{Receivables Management}

Company can sell goods on credit or cash. Cash sale is inflow of cash and it is controlled under cash flow analysis. But credit creates sundry debtors. Company has to receive money from them. If company starts to sell on return of cash, then it decreases the level of company's sale and profitability. On the other side, if company promotes credit sale, it can increase the risk of bad debts. So, it is required to control and to manage debtors.

It can be argued that revenue generation is the most crucial function of a company. Dot.com companies that create existing raw products and failed to generate significant revenue burned through their cash and ceased operating. Every company expends substandard resources to generate increasing levels of revenue.

However, that revenue must be converted into cash. Cash is the lifeblood of any company. Every dollar of a company's revenue becomes a receivable that must be managed and collected. Therefore, the staff and process that manage your receivables should:

- Manage $100 \%$ of your company's revenue.

- Serve as a service touch point for virtually all our customers (only sales and customer service speak mere with you customers.

- Can incur or save millions of dollars of bad debt and interest, and expense.

- Can injure or enhance customer service and satisfaction leading to increases or decreases in revenue.

Management of the Receivables is demanding task. The vast majority of companies expect that over $99.9 \%$ of all building will collected. Collecting ninety five percentage of revenue is not good enough. Companies will tolerate bad expenses of some but not much more. Which other department are expected to perform at $99 \%$ plus percentage effectiveness.

It is generally expected that a high percentage of novices will be paid on time and over $90 \%$ within 30 days of the due date. Management expects that the asset will be managed to promote sales and that all customers will be served promptly, courteously, and professionally. Astoundingly, most firms also expect this all to be accomplished for a cost equal to about two to three tenths of a percentage of revenue. 


\subsubsection{Inventory Management}

Inventory for manufacturing firm, managing inventory is vital. Inventory may consist of raw materials, work in process, and finished goods. The raw materials are to components and pars that are to be processed into a final product. Work in- progresses consist of goods under production. Finished goods are the completed units awaiting sale to customers. Each category will require special consideration and control. Failure of properly manage any category of inventory can be disastrous to a business. Overstocking raw materials or overproduction of finished goods will increase costs and obsolescence. Conversely, out - of - stock situations for raw materials will silence the production line at potentially great cost. Failure to have finished goods on hand might result in lost sales and customers (Larry \& Christopher, 2009).

A firm needs an inventory control system to effectively manage its inventory. There are several inventory control system in vogue in practice. They range from simple system to very complicated systems. The nature of business and the size dictate the choice of an inventory control system. For example, a small may operate a two-bin system. Under this system, the company maintains two bins. Once inventory in one bit is used, an orderly is placed, and meanwhile the firm uses inventory in the second bin. For a large departmental store that sells hundreds of items, this system is quit unsatisfactory. The department store will have to maintain a self - operating, automatic computer system for tracking the inventory position of various items and placing order. Below, there will be some focus on some inventory control system:

1. ABC Inventory Control System. Large numbers of firms have to maintain several types of inventories. It is not desirable to keep the same degree of control on all the items. The firm should pay maximum attention to those items whose value is the highest. The firm should, therefore, classify inventories to identify which items should receive the most effort in controlling. The firm should be selective in its approach to control investment in various types of inventories. This analytical approach is called the $\mathbf{A B C}$ analysis and tends to measure the significance of each item of inventory in terms of its value. The high-value items are classified as "A items" and would be under the tightest control. 'C items" represent relatively least value and would be under simple control. 'B items" fall in between these two categories and require reasonable attention of management. The ABC analysis concentrates on important items and is also known as control by importance and exception (CIE). As the items are classified in the importance of their relative value, this approach is also known as proportional value analysis (PVA).

2. Just - in - Time. JIT is a philosophy encouraging the firm to reduce inventories and produce goods as they needed. This philosophy treats any kind of inventory (raw materials, work in progress, and finished goods) as liabilities not assets. However, JIT is more than inventory management. It is a philosophy to eliminate the waste and improve efficiency. It takes inventory management a step further and changes the business process in order to enable it to return with no inventory and waste. It aims to reduce inventory to zero, increase throughput time, reduce lead - time and batch size. JIT also, required producing when needed. In this concept no goods are produced until it is demanded by customer or some other work station in the production line.

\subsection{Related Studies}

Working capital management has great influence of profitability, i.e, if the management takes good care of current assets in terms of their investment as well as finance and current liabilities, the firm surely will realize substantial profit. More exclusively, this means adequate investment in current assets which rules out excessive investment on one hand, and inadequate investment. Likewise, whenever financing is needed cash must be available to finance in current assets.

Nevertheless, if the management does well in that case, it also ought to care about the short term creditors and pay them when their debt is mature.

Firms should have excess of current assets (components of working capital) over current liabilities. The conventional rule is the current assets twice current liabilities. For example ,Hindustan manufacturing firm has a current ratio of 1.2:1; therefore, it may be interpreted to be insufficiently liquid. This rule is based on that in a worse situation, even if the value of current assets becomes half, the firm will be able to meet its obligation.

Working capital turnover ratio express the number of times a unit invested in working capital produces sales as the ratio is good since it shows up efficiency or inefficiency in the use of the whole or working capital and not merely a part of it, viz, that invested in stocks it is the whole of the working capital that leads to sales.

No matter, how profitable a business is unless it is adequately liquid it may fail. A business should be adequately liquid; it is possible for it to have too much current ratio. If too many resources are being held as current asset, it would make the two ratios appear healthy, but those resources could have been used more profitably. You don't get any interest on inventory. Too high a balance in a current account at the bank as means that resources are being wasted. 


\section{Methodology}

\subsection{Research Design}

The study will be conducted using descriptive correlation design. Descriptive studies are non experimental researches that describe the characteristics of a particular individual, or of a group. It deals with the relationship between variables, tasting of hypothesis and development of generalizations and use of theories that have universal validity. It also involves events that have already taken place and may be related to present conditions. Further, descriptive surveys are used to discover causal relationship (descriptive correlational), difference (descriptive comparative), to provide precise quantitative description and to observe behaviour.

\subsection{Research Population}

The target population will include a total of 104 operational staff and 30 managerial staff of he selected manufacturing firms in Benin City and other towns. The managerial staff will be involved because it is the planning body of the organizations and the operational staff being the implementers. Working capital management policies are basically established by the managerial body and generally utilized by the operational staff.

\subsubsection{Sample Size}

In view of the nature of the target population where the number for both operational staff and managers are many, a sample will be taken from each category. Table 1 below shows the respondents of the study with the following categories: district, target population and sample size. The Sloven's formula is used to determine the minimum sample size.

Table-1. Responding of the study.

\begin{tabular}{l|l|l|l|l}
\hline \multirow{2}{*}{ Firms Name } & \multicolumn{2}{|l|}{ Table Target Population } & Sample Size & \\
\cline { 2 - 5 } & Operational Staff & Managers & Operational Staff & Managers \\
\hline Benin City & 46 & 15 & 35 & 15 \\
\hline Other Town & 58 & 15 & 35 & 15 \\
\hline Total & $\mathbf{1 0 4}$ & $\mathbf{3 0}$ & $\mathbf{7 0}$ & $\mathbf{3 0}$ \\
\hline Grand Total & $\mathbf{1 3 4}$ & $\mathbf{1 0 0}$ & \multicolumn{2}{l}{} \\
\hline Source: Jones Orumwense.
\end{tabular}

The sample size of 100 was derived by using Sloven's formula as under:

$$
\begin{aligned}
& \mathrm{n}=\frac{\mathrm{N}}{1+\mathrm{Na}^{2}} \\
& \mathrm{n}=134(1+134 * 0.0025)=100
\end{aligned}
$$

\subsection{Sampling Procedures}

The purposive sampling will be utilized to select the respondent based on these criteria:

1. Employee respondents in any of the selected organizations are included in the study

2. Operational staff with working experience ranging from less than one year and above

3. Managers of the firms selected are under study

From the list of qualified respondents chosen based on the inclusion criteria, the sample random sampling will be used to finally select the respondents with consideration to the computed minimum sample size.

\subsection{Research Instruments}

The research tools that will be utilized in the study include the following (1) face sheet together data on the respondents' demographic characteristics (gender, age, qualifications, and number of years working experience); (2) standardized questionnaires to determine the levels of working capital management adopted from leanings of an oracle APPS Consultants for Receivable Management and from Tech Enterprise Resource Planning (ERP) for the inventory Management. These consist of options referring to cash management (14 items), receivable management (13) items and inventory management (14 items) in terms of indicators management. The response mood and scoring are as follows: for cash and receivable management absolutely right (4); right (3); wrong (2); absolutely wrong (1); for inventory management - strongly agree (4); agree (3); disagree (2); strongly agree (1).

While a researcher devised instrument will be adopted for the level of managerial performance (15 items). The response mode and scoring system of this instrument is as follows: surely true (4); true (3); untrue (2); surely untrue (1). 


\subsubsection{Validity and Reliability of the Instruments}

Content validity will be ensured by subjecting the research devised questionnaires on managerial performance to judgment by the content experts (who shall estimate the validity on the basis of their experience) such as professors (2), associate professors (2) and senior lecturers (3) in MBA field.

The test - retest technique will be used to determine the reliability (accuracy) of the researcher devised instrument to 5 qualified respondents, three from Benin City located organizations and two from other towns. These respondents will not include in the actual study. In this test - retest technique, the questionnaires will be administered twice to the same subject. If the test is reliable and the trait being measured is stable, the result will be consistent and essentially the same time.

\subsection{Data Analysis}

The frequency and percentage distribution will be used to determine the demographic characteristics of the respondents.

The mean and standard deviations will be applies for the levels of working capital management, and managerial performance. An item analysis will illustrate the strengths and weakness based on the indicators in terms of means and rank. From these strengths and weakness, the recommendations will be derived.

The following mean range will be used to arrive at the mean of the individual indications and interpretation:

\section{Mean Range}

3.26-4.00

2.5 $1-3.25$

$1.76-2.50$

$1.00-1.75$

B. For inventory management

\section{Mean Range}

3.26-4.0

2.51-3.25

$1.76-2.50$

1.00- 1.75

C. For the

Mean Range

3.26-4.00

2.51-3.25

$1.76-2.50$

$1.00-1.75$

\section{Response Mode}

Absolutely right

Right

Wrong

Absolutely wrong

\section{Response Mode}

Strongly agree

Agree

Disagree

Strongly disagree

erformance

\section{Response Mode}

Surely true

True

Untrue

Surely untrue

\section{Interpretation}

Very satisfactory

Satisfactory

Fair

Poor

\section{Interpretation}

Very Satisfactory

Satisfactory

Fair

Poor

\section{Interpretation}

Very satisfactory

Satisfactory

Fair

poor

Table-2. Profile of the respondent.

\begin{tabular}{|c|c|c|}
\hline Gender & Frequency & Percentage (\%) \\
\hline Male & 70 & 70.0 \\
\hline Female & 30 & 30.0 \\
\hline Total & 100 & 100.0 \\
\hline \multicolumn{3}{|l|}{ Age } \\
\hline $20-39$ & 54 & 54.0 \\
\hline $40-59$ & 33 & 33.0 \\
\hline 60 and above & 13 & 13.0 \\
\hline Total & 100 & 100.0 \\
\hline \multicolumn{3}{|l|}{ Qualification } \\
\hline Certificate & 10 & 10.0 \\
\hline Diploma & 24 & 24.0 \\
\hline Degree & 43 & 43.0 \\
\hline Postgraduate & 23 & 23.0 \\
\hline Total & 100 & 100.0 \\
\hline \multicolumn{3}{|l|}{ Experience } \\
\hline Less than 1 year & 9 & 9.0 \\
\hline $1-2$ yrs & 21 & 21.0 \\
\hline $3-4$ yrs & 30 & 30.0 \\
\hline $5-6$ yrs & 20 & 20.0 \\
\hline $7 \mathrm{yrs}$ & 20 & 20.0 \\
\hline Total & 100 & 100.0 \\
\hline
\end{tabular}

Source: Primary data, 2011 
From the above Table 1, it is indicated that different categories were involved in the study. And $70 \%$ of the respondents were male, whereas, the other $30 \%$ of the respondents were female, so it is obvious that the two firms were dominated by male workers.

The findings of the study showed that the majority of the workers i.e. 54\% lay between 20-39 of age, and $30 \%$ of the respondents were $40-59$ of age i.e. middle adult hood. But the minority of the respondent was in the age bracket of 60 and above. According to the findings, it is clear that the selected manufacturing firms tended to employ young people at the age bracket of $20-39$.

Table 1 also showed that the finding of the of the study indicated that the majority of the respondent were Degree holder which make up $43 \%$ of the respondent $24 \%$ of the respondents, the third group of the respondents were postgraduate i.e. Master and $\mathrm{PhD}$ holder which represented $23 \%$ of the respondents.

Likewise, the findings reveal that the majority of the respondents had the experience of $3-4$ years of work; this makes up $30 \%$ of the total respondents, whereas $21 \%, 20 \%$ were represented by the respondents whose experience were $1-2$ years and $5-6$ years respectively. Those with the 7 and above years of experience represented $20 \%$ of the respondents. But the fledgling workers with the less than 1 year of experience were the minority group among the respondents and they represented $9 \%$.

\section{Findings, Conclusions and Recommendations 5.1. Summary of the Findings}

This study was guided by four objectives which consist of these (1) to determine the demographic characteristic of the population in terms of: age, gender, level of education, and experience of respondents working in the selected manufacturing firm (2) To determine the level of working capital management of the selected manufacturing firms (3) to determine the level of managerial performance of the selected manufacturing firms (4) to establish if there is a significant relationship between the levels of working capital management and managerial performance of the selected manufacturing firms in the study.

The first objective of the study, the descriptive statistic showed frequencies and percentages, indicating the characteristics of the respondents and also showed the distribution of the population in the study. The result indicated that man dominated the selected manufacturing firms.

And also findings indicated that diverse age among the workers in the selected manufacturing firms, different ages form youth to old aged who have information in the field of study and can provide useful information to the study.

In addition to that, the findings have revealed that majority of the respondents have degree, while the minority hold master and PHD. This shows that the workers are not high in the education hierarchy and consequently knowledge shortage and skills.

The second objective was to determine the level of working capital management in the selected manufacturing firms. Based on the analysis of chapter four, the findings revealed that most of the respondent agreed that working capital management indicator/component namely cash management as satisfied in view of the questions asked and the mean average for that ranged from 3.01 to 2.52. But cash management in terms of deposit floating has showed a mean of 2.26 which means majority of the respondent believe that the selected manufacturing firms' deposit float longer which adversely effects the efficiency of cash management of the selected manufacturing firms.

Type of payment the firms receives and allowance of the firms to internal rating of receivables against outstanding payables have average means of 1.30 and 1.25 respectively. This means that the majority of the respondents have agreed that the selected manufacturing firms do not allow internal netting of receivable against outstanding payables, while the minority agreed that the firms do internal netting of receivables against outstanding payables. This is to say that the policy regarding internal netting of the selected manufacturing firms is poor.

Fir the receivables management indicator, the table has shown that the receivables management policies of the selected manufacturing firms are satisfactory, because the mean average calculated for the receivable management indicators ranged from 3.15 to 2.07 and this is evidence for satisfactoriness. But one indicator with the man of 1.14 vis-à-vis tracking and recording relationship of customers had evidence that the majority of the respondents agreed that the selected firms do not track record the relationship with their customers.

This shows that the selected manufacturing firms' policy with respect to track recording of the relationship with the customer is poor.

Inventory management indicator in Table $3 \mathrm{C}$ shows that most of the policies are satisfactory because their means range from 3.98 to 2.61. On the other hand, there are some policies like materials released from stores, and receiving, recording, storing and giving of inspection results read means of 2.50, 1.12, and 1.09 respectively which per se is evidence for fair for the first and poor for the last two.

The third objective of the study was to determine the level of managerial performance; accordingly, the findings revealed that the majority of the respondents have agreed that the managerial performance indicators were satisfactory. But the most important indicator viz. organization's earning was poor.

The fourth objective was to determine if there is a relationship between the level of working capital management and the level of managerial performance for the selected manufacturing firms, and the resultant 
correlation computed as 0.472 with a level of significance at .000 shows that there is a significant relation between the two variables. Based on this, the study reveals that the two variables are strongly correlated.

\section{Conclusion}

Based on the findings of the study the following conclusions are drawn: Level of Working Capital Management in the selected Manufacturing Firms.

According to the analysis the average mean of level of working capital management is 2.25, which shows that majority of the respondents agreed that the level of working capital management is fair because the mean is in between $1.76-2.50$.

\subsection{Level of Managerial Performance}

As indicated in the analysis of chapter four, the average mean of the level of managerial performance of the selected manufacturing companies is 2.19 , this indicated that majority of the respondents agreed that the managerial performance of the manufacturing firms is varies according to the average mean which lays in between 1.76-2.50.

Working Capital Management and Managerial Performance in Selected Manufacturing Companies in Edo State, Nigeria.

This objective of the study was established the effects of working capital management on managerial performance for the selected manufacturing firms in Edo State, for which it was hypothesized that there is no effect of working capital management on the managerial performance. Basing of firms result, the researcher rejected the null hypotheses. The other option is to accept the researcher, the there is a correlation between the two variable. The researcher suggested and generated the following conclusions;

If the managerial staff who are in charge of the selected manufacturing firms manage well working capital by adopting effective policies, it will lead to good managerial performance given the situation is good.

\section{Recommendation}

The researcher suggests to the selected manufacturing firms to pay attention to the crucial policy of internal netting of receivable against outstanding payables, because it is a crucial factor which if they do not do may cause problem like overwhelming of outstanding payable over the receivable and winding of the business.

Also another suggestion is to separation responsibilities of receiving, recording, and storing of goods, if not material assets lost or vandalized.

Another suggestion for the selected manufacturing firms is to capitalize on the police they adopt which were rated as satisfactory or over satisfactory.

Last and final suggestion for the selected manufacturing firms is to train their managers and get themselves used to, because the firms' success and good managerial performance is vested in it.

Suggested Areas for Further Research

On the basis of the knowledge of the research gained during this study, the research would recommend the main topic which are important in the field of working capital management

- Working capital management in recession and Maximization of wealth

- Financing Long -term Assets and Project Success

\section{References}

Connor, D. (2011). How to survive and thrive) in a recession.

Deloof, M. (2003). Does working capital management affects profitability of Belgian firms? Journal of Business Finance and Accounting, 30(3\&4), $573-587$.

Ghosh, S. K., \& Maji, S. G. (2003). Working capital management efficiency: A study on the Indian cement industry. The Institute of Cost and works Accounts of India.

Karthikeyan, N. (2011). Working capital.

Larry, M., \& Christopher, J. (2009). Managerial and cost accounting ventures publishing APS.

Mathur, S. N. (2010). Working capital management of the cement industry in India-a comparative analysis of selected units.

Padachi, K. (2006). Trends in working capital management and its impact on firms performance: Analysis off Mauritian small manufacturing firms. International Review of Business Research Papers, 2(2), 45-58.

\section{Bibliography}

Ali, W. (2010). Relationship between the profitability and working capital policy of the Swedish companies.

Amin, E. (2005). Social science research: Concept, methodology, and analysis. Kampala: Makerere.

Deloof, M., \& Jegers, M. (1996). Trade credit, product quality, and intra group trade: Some European evidence. Financial Management, 25(3): 33-43.

Eljelly, A. (2004). Liquidity-profitability trade-off. an empirical investigation in an emerging market. International Journal of Commerce and Management, 14(2): 48-61.

Gilman, L.J. (1991). Principles of managerial finance. Now York: Collins Publishers Inc. Harper. 
Hausman, J.A. (1978). Specification tests in econometrics. Econometrics, 46: 1251-71.

Jose, M.L., Lancaster, C. \& Stevens, J.L. (1996). Corporate returns and cash conversion cycles. Journal of Economics and Finance, 20(1): 33-46.

Joshi, P.V. (1995). Working capital management under inflation. 1st Edn., Anmol Publishers. pp: $20-93$.

Kargar, J. \& Blumenthal, R.A. (1994). Leverage impact of working capital in small business. TMA, Journal, 14(6): 46-53.

Lazaridis, I. \& Tryfonidis, D. (2006). Relationship between working capital management and profitability of listed companies in the Athens stock exchange. Journal off Financial Management and Analysis, 19(1): 26-35.

Mukhopadyay, D. (2004). Working capital management in heavy engineering firms-a case study. Available from: myicwai.com/knowledge-bank/fm48.

Oso, W. Y. \& Onen, D. (2008). Writing research proposal and report. 2nd Edn.

Panday, I.M. (1983). Management accounting: Vikas Ltd.

Panday, I.M. (2005). Financial management. 9th Edn., Vikas Publishing House Ltd.

Raheman, A. \& Nasr, M. (2007). Working capital management and profitability-case of Pakistani firms. International Review of Business Research Papers, 3(2): 275-296.

Shukla, M.C., Grewal, T.S. \& Gupta, S.C. (2005). Advanced accounts. S. Chand and Company Ltd.

Wood, F., \& Sangster, A. (2008). Business accounting. 11 th Edn., Pearson Education Ltd. 